\title{
RACE, JUSTICE, POLICING, AND THE 2016 AMERICAN PRESIDENTIAL ELECTION
}

\author{
Kevin Drakulich \\ School of Criminology and Criminal Justice, Northeastern University \\ John Hagan \\ Department of Sociology, Northwestern University and American Bar Foundation \\ Devon Johnson \\ Department of Criminology, Law and Society, George Mason University \\ Kevin H. Wozniak \\ Sociology Department, University of Massachusetts Boston
}

\begin{abstract}
Scholars have long been interested in the intersection of race, crime, justice, and presidential politics, focusing particularly on the "southern strategy" and the "war on crime." A recent string of highly-publicized citizen deaths at the hands of police and the emergence of the Black Lives Matter movement have brought renewed visibility to this racially-driven intersection, and in particular to issues involving contact with and attitudes toward the police. Using data from the 2016 Pilot Study of the American National Election Studies, this study explores how contact with the criminal justice system and perceptions of police injustice shape political behavior in the modern era, with a specific emphasis on prospective participation and candidate choice in the 2016 presidential election. The results indicate that being stopped by the police - an experience that can feel invasive and unjust-may motivate political participation, while spending time in jail or prison-an experience associated with a marginalization from mainstream civic life-appears to discourage political participation. Perceiving the police as discriminatory also seems to motivate political engagement and participation, though in opposite directions for conservative versus liberal voters. In addition, perceptions of police injustice were related to candidate choice, driving voters away from Donald Trump. Affective feelings about the police were not associated with candidate choice. Perceptions of the police appear to act in part as a proxy for racial resentments, at least among potential voters in the Republican primary. In sum, the intersection of race, justice, and policing remains highly relevant in U.S. politics.
\end{abstract}

Keywords: Political Participation, Vote Choice, Criminal Justice Contact, Perceived Police Injustice, Policing, Racial Attitudes, Black Lives Matter

Du Bois Review, 14:1 (2017) 7-33.

(C) 2016 Hutchins Center for African and African American Research 1742-058X/16 \$15.00

doi:10.1017/S1742058X1600031X 


\section{INTRODUCTION}

For decades, American scholars have studied the intersection of race, crime, justice, and presidential politics, focusing particularly on the Goldwater, Nixon, and Reagan eras, which were characterized by the emergence and success of the Republican "southern strategy" and broader themes of "law and order" and "war on crime." Recently, a series of highly-publicized deaths of African American citizens during encounters with police - and the Black Lives Matter movement that has emerged in their wakehave increased the visibility of this racially-driven intersection, drawing political attention to issues involving contact with and attitudes toward the police.

The present study explores the impact of these events on the shape and directions of national political behavior in the contemporary era. We posit that citizen contact with the criminal justice system and perceptions of the police, in conjunction with racial feelings and resentments, are likely to be highly influential in predicting candidate selection and the likelihood of citizen participation in the 2016 Presidential election. We test this perspective using data from the 2016 Pilot Study of the American National Election Studies, a representative survey of voting-age citizens in the United States. In new and revealing ways, the results suggest that political behavior in the 2016 presidential election will be influenced by citizens' experiences with and attitudes about race, justice, and policing, adding a new chapter to the long American history of race, crime, and presidential politics.

\section{CONTEMPORARY POLITICAL BEHAVIOR IN U.S. RACIAL HISTORICAL CONTEXT}

To understand the current political climate surrounding race, crime, and the 2016 presidential election, it is helpful to consider how these issues became intertwined in the midst of the Civil Rights era. In 1961 and 1962, as organizations began to register Black voters across southern states where post-Reconstruction policies had disenfranchised them (McAdam 1988), Southern politicians who were threatened by the massive change that would accompany an enfranchised African American electorate began redefining political action in support of these policies as disorderly and unlawful (Beckett 1997; Beckett and Sasson, 2004; Tonry 2011; Wacquant 2005; Weaver 2007). Efforts to register voters or otherwise advocate for political civil rights were also met with violent repression, often organized by the state through the mobilization of the police (Branch 1998; Hampton and Fayer, 1990).

In the summer of 1964, mass racial protests and violence erupted in Rochester, Harlem, and Philadelphia. Similar protests and violence occurred during the Watts Rebellion in Los Angeles in the summer of 1965, and in Detroit, Newark and other cities across the country throughout the summer of 1967. Each of these uprisings was sparked by a specific incident of perceived police mistreatment of Black citizens, although in each case tensions were already high between the police and the Black community.

As a result of these political and social actions, segregation, Black disenfranchisement, urban unrest, and law and order were major themes in several presidential elections, beginning with the transformative and consequential 1964 election. From the end of Reconstruction-when White southerners, including many former Confederate soldiers and politicians, re-established social and political dominance over Blacks in their states-until 1964, voters in "deep south" states had reliably voted against Republican presidential candidates. ${ }^{1}$ The 1964 presidential election brought a reversal of this trend; for the first time, deep south states voted for the Republican candidate, Barry Goldwater, 
while the majority of the country voted for Democrat Lyndon B. Johnson. This pattern has persisted over time, with the deep south consistently voting against the Democratic presidential candidate ever since. ${ }^{2}$

The 1964 election was consequential for a variety of reasons. It was the first stage of the "southern strategy," where Republicans attempted to peel large numbers of southern White voters away from the Democratic Party by appealing to their discomfort with the racial changes posed by the Civil Rights Movement (Carmines and Stimson, 1989; Edsall and Edsall, 1991; Tonry 2011; Wacquant 2005). The 1964 election also saw the emergence of a racially-coded "tough on crime" rhetoric that initially sought to criminalize those involved in political protest, and which later evolved into support for "wars" on crime and drugs in the 1980s and 1990s (Beckett 1997; Weaver 2007). The policies and practices of these "wars" ultimately resulted in a significant uptick in aggressive policing tactics and massive increases in state and federal incarceration, all of which disproportionately affected Black communities (Alexander 2010; Beckett and Sasson, 2004; National Research Council 2014; Tonry 2011). In addition, the 1964 presidential contest, and the election of Lyndon Johnson, also marked a major moment for the civil rights movement. Lyndon Johnson was able to mobilize congressional support and passage of the Civil Rights Act of 1964, the Voting Rights Act of 1965 , and eventually the Civil Rights Act of 1968.

Lessons from this era suggest a basic model for understanding the role of race, crime, and the police in politics: issues of crime and policing are invoked not only as part of strategies to maintain status-quo racial group positions in the face of perceived threats, but also in efforts to challenge this status quo (Beckett and Sasson, 2004; Blumer 1958; Feagin 2009; Tonry 2011). When protestors in the 1960s sought to draw attention to the mistreatment of Black citizens by the police as well as other issues of racial equality, some political actors responded by reframing these protests as promoting lawlessness and disorder and by otherwise highlighting images of Black crime to delegitimize the protesters' grievances and call to action (Beckett 1997; Beckett and Sasson, 2004; Tonry 2011; Wacquant 2005; Weaver 2007). This "law and order" and "tough on crime" rhetoric served as a racial "dog whistle" (López 2014), rallying support from those opposed to the expansion of African Americans' civil rights, a usage that continues in subsequent elections, especially during the "wars" on crime and drugs (Beckett 1997; Beckett and Sasson, 2004; Edsall and Edsall, 1991; Tonry 2011). In addition, the criminal justice system was used as part of the effort to reclaim White dominance in the political sphere through the criminalization of political protest and voter registration efforts, intimidation of prospective voters, and eventual state-level revocations of voting rights through felon disenfranchisement laws (Beckett and Sasson, 2004; Behrens et al., 2003; Manza and Uggen, 2006: Tonry 2011; Uggen and Manza, 2002). On the other hand, widespread perceptions of injustice-rooted in real bias and mistreatment on the part of the criminal justice system, and in particular the police-served as a flashpoint to motivate and rally support for civil rights efforts (Branch 1998).

\section{The 2016 Presidential Election}

The politics of race, crime, and criminal justice that emerged in the 1960s left an indelible mark on the American electorate. Despite progress over the last sixty years, race has retained critical importance in American politics, and issues involving crime and the police remain highly racialized.

In a striking parallel to the events of the early 1960s, public and political attention to the relationship between the police and the Black community increased significantly 
following the deaths of many Black citizens during encounters with police in the years preceding the 2016 election. Attention to police treatment of African American suspects began with the deaths of Eric Garner in New York City and Michael Brown in Ferguson, Missouri, and continued through the deaths of Tamir Rice, Freddie Gray, Laquan McDonald, Alton Sterling, Philandro Castile, and Terence Crutcher, among others. These events have inspired mass public protests in cities such as Ferguson, St. Louis, New York, Baltimore, Cleveland, Baton Rouge, and St. Paul. In an echo of the past, some politicians have framed the protests as disorderly, violent, and unlawful, while expressing strong support for the police (Campbell 2015; Diamond 2016; Stranahan 2016).

These events have intensified the social and political action of the Black Lives Matter movement, and have revived a national dialogue about police biases and brutality against African American citizens and discriminatory criminal justice practices more generally. This is all occurring at the same time that a bipartisan coalition of politicians is pushing for criminal justice reform (Grawert 2016; Whack 2016). Black Lives Matter activists have protested at campaign events of both Democratic and Republican presidential candidates as political rhetoric about race, crime, and criminal justice in U.S. presidential politics has been re-energized. The result is a revival of framing and counterframing efforts utilizing the symbolic value of these issues to address questions about the relative status of racial groups in the United States.

The major party presidential candidates have distinct positions on crime and policing issues. Republican candidate Donald Trump has explicitly identified himself as pro-police and pro-"law and order" (Alcindor 2016); he has made claims about "inner-city crime" reaching record levels (Fields 2016), and infamously tweeted false and misleading statistics about African Americans and violent crime (Greenberg 2015). Trump has resisted holding police accountable for unprovoked violence against citizens (Greenberg 2015) and has openly criticized the Black Lives Matter Movement, saying in September of 2015 that "I think they're trouble. I think they're looking for trouble" (Campbell 2015). In November 2015, he commented on an incident where a Black Lives Matter demonstrator had allegedly been assaulted by Trump supporters, noting that "maybe he should have been roughed up" (Johnson and Jordan, 2015). Although Trump is not alone in his views, his rhetoric is widely seen as inflammatory. His responses may yield support from White voters who feel they have lost status relative to minorities, and-at the extreme-from White nationalists (Berger 2016; Confessore 2016; Klinker 2016). In short, then, it appears that crime and justice rhetoric is once again being used to signal to those concerned about threats to the status quo racial hierarchy.

Democratic candidate Hillary Clinton has been criticized for her association with the 1994 Clinton Crime Bill and mass incarceration, and for her use of racially-coded language when referring to juvenile offenders as "superpredators" during the 1990s (Capehart 2016). Clinton has since repudiated a "tough on crime" policy approach (Beinart 2015), openly called for reform in the aftermath of the 2015 Baltimore protests following the death of Freddie Gray while in police custody (Bouie 2015; Grawert 2016). Her positions on criminal justice reform set her apart from Democratic candidates in previous elections. Her reform efforts align with some of the concerns raised by the Black Lives Matter movement, and she has used injustice frames to rally support among those concerned about the differential treatment of Black citizens by the police and the relative status of Black citizens more generally. In sum, the anecdotal evidence suggests that issues of crime, justice, and policing are highly salient-and fiercely contested - in the 2016 presidential election. 
Our goal is to assess the general impact of these recent developments on the 2016 presidential election. Specifically, we are interested in the influence of two distinct factors on prospective political participation and candidate choice in the 2016 election: 1) contemporary citizen contact with the criminal justice system; and 2) perceptions of police injustice. In the following section, we review research and further develop a theoretical model for this purpose.

\section{RESEARCH AND THEORY ABOUT JUSTICE SYSTEM CONTACT, PERCEPTIONS OF POLICE INJUSTICE, AND POLITICAL BEHAVIOR}

\section{Criminal Justice Contact}

Police stops and questioning have increased in recent decades and are often justified by police authorities as aggressive or zero-tolerance strategies for misdemeanor, morality, and "broken window" law enforcement. These police actions are often referred to as "Terry stops," in reference to Terry v. Obio 392 U.S. 1 (1968), which effectively lowered the evidentiary requirement from "probable cause" to "reasonable suspicion" of an infraction. Such stops rarely result in arrests or convictions and disproportionately target economically disadvantaged, minority citizens. At the height of this policy in New York City in 2011, for instance, 685,724 stops were made, with no charges or arrests in $88 \%$ of the cases. ${ }^{3}$ More than half of the citizens stopped were Black (53\%), with Latinos making up more than half of the remaining stops (34\%).

Given the number and the racial and ethnic disproportionality of the stops, it is unsurprising that many perceive them to be unjust (Fagan and Davies, 2000; Gau and Brunson, 2010; Silverman and Della-Giustina, 2001; Tyler and Waslak, 2004; Weitzer and Tuch, 2004a, b). Among those who feel a stop was unwarranted and/or the product of police bias, the experience can be humiliating and infuriating. For many, police stops may be their primary point of contact with the criminal justice system and their main point of contact with the government.

Work on procedural justice suggests that when the police are perceived to be disrespectful or biased, compliance and cooperation with law enforcement suffers (Brunson and Weitzer, 2009; Tyler and Waslak, 2004; Weitzer and Tuch, 2005). One consequence of this is a sense of legal cynicism-a cultural frame in which the police are seen not only seen as unjust and therefore illegitimate, but also as failing at crime prevention, protection, and in providing public safety (Anderson 1999; Carr et al., 2007; Hagan et al., 2016; Kirk and Papachristos, 2011; Kirk and Matsuda, 2011; Sampson and Bartusch, 1998).

In addition to aggressive police stops, incarceration has increased dramatically since the 1970s, and has disproportionately affected minority citizens (Rosich 2007; Western 2006). Recent research documents the devastating personal, familial, social, and economic consequences of incarceration (Clear 2007; Clear and Frost, 2014; Mauer and Chesney-Lind, 2002; Western 2006), resulting in long term exclusion from mainstream civic and public life (Lerman and Weaver, 2014; Levy-Pounds 2013; Pettit 2012; Pettit and Western, 2004; Travis 2002). Crucially in terms of political enfranchisement, many currently or formerly incarcerated persons are legally prohibited from voting (Manza and Uggen, 2006).

\section{Perceptions of Police Injustice}

One consequence of negative encounters with the police is perceived police injustice (see Gau and Brunson, 2010; Hagan and Albonetti, 1982; Hagan et al. 2005; 
Wortley et al., 1997). These perceptions can proliferate as a result of both direct and indirect experience. Thus exposure to news coverage of police abuses provokes more critical views of the police, even among Whites who generally have more positive baseline views of the police (Weitzer and Tuch, 2004a, b). In contrast, racial animus toward Blacks can diminish perceptions of racial injustice by the police and the justice system more broadly (Drakulich 2015a, b; Matsueda and Drakulich, 2009).

Police practices and (mis)behavior vary both across the race of individuals who encounter the police (e.g., Fryer 2016) and the racial composition of neighborhoods (Brunson and Weitzer, 2009; Fagan and Davies, 2000; Hagan and Albonetti, 1982; Kane 2002; Mastrofski et al., 2002; Smith 1986; Terrill and Reisig, 2003; Waddington and Braddock, 1991; Weitzer and Tuch, 1999, 2002), with interracial differences in perceptions of the police explained largely by differential experiences with the police (Brunson and Weitzer, 2009; Hagan et al., 2005; Hurst et al., 2000; Skogan 2005; Weitzer and Tuch, 2004b). One consequence is a "crisis of legitimacy," in which perceptions of police bias influence citizen views of police responsiveness as well as their likely behavior serving on juries in cases where the police may have acted in biased ways (Bobo and Thompson, 2006, p. 467). High-profile incidents of police misconduct even appear to suppress the public's willingness to call 911 (Desmond et al., 2016).

Perceptions of police actions are distinguishable from general affective evaluations of the police. In the recent context of the Black Lives Matter movement and proposed police reform, some politicians and voters have been accused of being motivated by a dislike or hatred of the police (Greer 2015), while other have expressed strong affective endorsements of the police (Nuzzi 2016). One interpretation is that such views represent an expressive concern: that "hating" the police, or, alternatively, "loving" the police, and, indeed, voting on the basis of it, is an expression of one's identity (Brennan and Hamlin, 1998).

\section{Political Behavior}

Our collective responses to rule violations are fundamental to the operation of society, and our justice system represents one of the largest and most impactful public institutions. Thus, there are good reasons to suspect that contact with the criminal justice system as well as broader beliefs about the fairness of the system are likely to impact political engagement, participation, and candidate choice.

There are several key mechanisms by which criminal justice contact and perceptions of police injustice may be related to political behavior. A line of political thought with a long history suggests that government institutions matter to the development of its citizens' political behavior. Alexis de Tocqueville (2004[1840]), for example, wrote of the importance of jury service in educating citizens about the purposes of the justice system. More recent work similarly suggests that people's interactions with government representatives and institutions are important mechanisms by which citizens learn about the political process and civic matters more broadly (Landy 1993; Lipsky 1980; Soss 2005). Scholars like Joe Soss (2005) have found that direct contact with government agents plays a particularly important role in shaping how poorer and more marginalized people perceive government, writ large.

More recently, Amy Lerman and Vesla Weaver (2014) tested the relationship between justice system contact and political behavior using the National Longitudinal Study of Adolescent Health and the Fragile Families and Child Wellbeing Study. Lerman and Weaver argue that contact with agents of law enforcement is unlike contact with other government bureaucracies and suggest that this contact can have profound effects on views of the government, the civic body, and the place of the citizen within it. 
In fact, they found that citizens often form their opinions about the entire government based almost exclusively upon their personal experience with the criminal justice system. As a result, these citizens often see the focus of government to be the exercise of control, not the provision of services or the protection of citizens. This can result in the kind of legal cynicism noted above (see especially Kirk and Papachristos, 2011; Hagan et al., 2016).

Lerman and Weaver's research uncovered weak, negative relationships between arrest, conviction, imprisonment, and "low-impact" political activities like contacting a representative; but the negative effects were much stronger on the likelihood of registering to vote or voting in the previous presidential election. The magnitude of the effect on political behavior increased with the punitiveness of the justice system encounter, and was robust to controls for differences in socioeconomic status, demographic factors, and even respondent drug use. These results suggest that the experience of being arrested and/or punished by the justice system may lead citizens to believe that they are part of a stigmatized class that has been symbolically severed from the polity. The implication is that such contact is marginalizing and exclusionary, driving citizens away from political engagement and participation.

However, Lerman and Weaver (2014) also discovered an unexpected (but small in magnitude) positive relationship between simply being questioned by police and political activities like engagement in civic organizations or contacting a representative. Consistent with this "unexpected" finding, Victor Rios (2011) finds that disadvantaged youth who have experienced police harassment become more politically engaged in order to protest perceived injustice. In sum, it appears that very punitive encounters with the criminal justice system such as incarceration may drive individuals away from political participation, while less impactful actions such as police stops may actually increase engagement and participation.

Perceptions of police injustice may be relevant to political behavior for at least two reasons. The first draws on an idea from the collective action framing perspective, which describes how actors seek to frame social problems for political purposes (Benford and Snow, 2000; Gitlin 1980; Goffman 1974). The goals of such framing efforts are to build consensus around the causes of and solutions to a problem, but also to motivate action around an issue. To spur such action, frames will emphasize the severity and urgency of the negative consequences of the issue, but they may also emphasize a moral imperative-the propriety or rightness of action (Benford 1993). As such, viewing a problem as an injustice rather than a misfortune can be a powerful motivating frame for an issue (Snow and Benford, 1992; Turner 1969). Thus, perceptions of police behavior not just as unfortunate but as unjust may motivate both political participation and support for political candidates whose statements conform to such a justice frame.

In line with this perspective, anecdotal evidence suggests that the death of Michael Brown, viewed by many as the result of an unjust police action, prompted increased turnout for local elections in Ferguson, Missouri (Eligon 2015). In addition, research shows that perceptions of police injustice may be related to candidate choice. Using a 2006 political survey, Ross Matsueda and colleagues (2011) found that perceptions of police injustice were associated with a reduced likelihood of the respondent reporting that they would vote for George W. Bush over Bill Clinton in a hypothetical election, even after controlling for political party and ideological identification.

Another possibility deserves further consideration: that pro-police rhetoric or perceptions of the police as fair may also motivate political participation and increase support for candidates espousing similar rhetorical and perceptual frames. As noted above, some politicians have used references to crime to signal and attract voters who 
are uncomfortable with perceived changes in the relative standing of racial groups (Beckett and Sasson, 2004; Edsall and Edsall, 1991; Hagan 2010; Mendelberg 1997; Tonry 2011). Recent work suggests this connection between racialized feelings and perceptions of crime and (in)justice persists (Drakulich 2015a, b) and polarizes voters into two camps: those who perceive the police to be fair, impartial protectors of lawabiding citizens; and those who perceive the police (and the broader justice system) to be prejudicially biased and punitively discriminatory against minority citizens (Peffley and Hurwitz, 2010).

This raises a final important consideration. If crime and justice rhetoric is frequently employed as a signal to voters concerned about threats to the existing racial order, this suggests that these views may act, in part, as a proxy for racial feelings and attitudes. Indeed, abundant evidence demonstrates a connection between racial feelings, attitudes, and perceptions of crime and justice, including perceptions of crime as a problem, explanations for racial disparities in contact with the criminal justice system, and support for punitive responses to crime (Bobo and Johnson, 2004; Drakulich 2015a, b; Johnson 2001, 2008, 2009; Matsueda and Drakulich, 2009; Soss et al., 2003; Unnever and Cullen, 2007, 2010; Wozniak 2016). In addition, prior work has also identified a direct role for racial feelings and attitudes in voter choice (McElwee and McDaniel, 2016).

Key to this discussion is an understanding of the often hidden or implicit role of racial anxieties and racism in contemporary politics. Beginning in the Civil Rights era, open expressions of racial antipathy towards Blacks declined and were replaced by a norm of equality (Mendelberg 2001). Contemporaneously, new racial logic emerged that deemphasized racial group distinctions in favor of individualism, while ignoring that not all individuals have the same opportunities given historical group disparities (Feagin 2009; Jackman and Muha, 1984; Schuman et al., 1997). Scholars have described this new racial logic-which serves to maintain inequalities by rejecting group demands - as symbolic, laissez-faire, or colorblind racism (Bobo 2004; Bobo and Kluegel, 1997; Bobo and Smith, 1998; Bobo et al., 1997; Bonilla-Silva 2010; Kinder 1986; Kinder and Sears, 1981; Sears 1988). As a result, politicians have relied on implicit racial messaging and racial code words (such as "law and order") to appeal to White voters concerned about relative racial group positions without overtly referencing race (López 2014; Mendelberg 2001). Thus, it is possible that views of the police serve as proxies for racial feelings and attitudes. Ross Matsueda and Kevin Drakulich (2009), for example, find that perceptions of police injustice are associated with a variety of political policy positions through an association with racial resentment. This measure represents one attempt to capture this new racial logic (Henry and Sears, 2002).

\section{Research Questions}

In light of the theory and research evidence reviewed above, we explore several key questions about the role of criminal justice contact and perceptions of police injustice in the 2016 U. S. presidential election.

The first question involves the impact of criminal justice contact on political participation. Negative police contact, especially if it is perceived to be unjust, may motivate political participation with the goal of changing the system. However, criminal justice contact that results in stigmatic marginalization or exclusion may deter individuals from participating. Our hypothesis is therefore that police stops motivate political action, while incarceration decreases political participation. A second related question focuses on the impact of police contact on candidate choice. Our hypothesis is that 
experience with police stops motivates support for Democratic presidential nominee Hillary Clinton. In this election, there were clear distinctions between the criminal justice policy positions of the major party candidates. Both major Democratic candidates (Hillary Clinton and Bernie Sanders) advocated for criminal justice and police reform. The major Republican candidates generally, and the eventual nominee Donald Trump in particular, tended to express support for the police rather than propose police reform.

The third and fourth questions involve the impact of perceived police injustice on political participation and candidate choice. Once again, several hypotheses present themselves. Perceptions of injustice may act as a powerful motivational frame inspiring political participation and support for candidates who promote justice-relevant reforms. However, views of the police as fundamentally fair may serve as a rallying cry for those on the other side of the political spectrum, especially in an election year in which the police are perceived to be unfairly criticized. In other words, strong views either way may drive both groups to the voting booth, but to vote for different candidates. This suggests a potentially strong effect on candidate choice, but also the possibility of a confounding effect on participation.

A fifth question asks whether the role of perceived police injustice can be distinguished from a more general affective evaluation of the police, or in simplistic terms: "hatred of the police." Given our theoretical perspective on why perceptions of injustice matter, we expect the role of perceived injustice to be both independent of, and more important than, affective evaluations of the police.

A final question, based on the long history of law and order rhetoric being used as a racial code word or dog whistle, asks whether the effect of these feelings about attitudes or the police are independent of measures of feelings and attitudes about race.

\section{METHODOLOGY}

\section{Data}

To test the impact of recent experiences with and attitudes toward police and the criminal justice system, the American National Election Studies agreed to include questions about criminal justice contact and perceptions in their 2016 Pilot Survey (ANES 2016). The ANES collected surveys from 1200 respondents and included weights designed to make the sample representative of the larger population of U.S. citizens age eighteen or older on the basis of age, gender, race-ethnicity, education, region, and party identification. ${ }^{4}$ The survey was conducted over the internet drawing on respondents from an existing panel..$^{5}$ The survey was conducted in late January 2016, just before primary voting began in early February.

\section{Measures}

\section{Political Behavior}

The analysis seeks to explain two forms of political behavior: participation and choice. Participation is captured by two indicators. The first is a measure of engagement, asking respondents to rate themselves on a scale reflecting how frequently they "follow what's going on in government and public affairs" (ranging from "hardly at all" to "most of the time"). The second measure captures intended behavior, the self-assessed percent chance, on a scale from zero to 100 that the respondent will vote in 2016. Table 1 describes the sample on key variables. ${ }^{6}$ The majority of respondents- $78 \%$ reported that they followed politics some or all of the time, and respondents on average 
Table 1. Descriptive Information for the Sample on Key Measures

\begin{tabular}{|c|c|c|c|c|c|}
\hline & $\begin{array}{c}\text { Full } \\
\text { sample }\end{array}$ & Whites & Blacks & Clinton & Trump \\
\hline Political engagement, participation, and choice: & $\%$ & & & & \\
\hline$\overline{\text { Follow politics some or most of the time }}$ & 78.2 & 79.3 & 71.9 & 85.0 & 90.2 \\
\hline $\begin{array}{l}\text { Percent chance of voting in } 2016 \text { Presidential } \\
\text { election }\end{array}$ & 78.8 & 81.7 & 77.5 & 82.8 & 87.3 \\
\hline $\begin{array}{l}\text { Prefer Donald Trump among Republican } \\
\text { candidates }\end{array}$ & 33.5 & 38.1 & $13.5^{* * *}$ & & \\
\hline $\begin{array}{l}\text { Prefer Donald Trump in general election } \\
\text { versus Hillary Clinton }\end{array}$ & 36.5 & 41.8 & $8.9^{* * *}$ & & \\
\hline \multicolumn{6}{|l|}{ Criminal justice contact: } \\
\hline Ever stopped by the police & 58.5 & 60.9 & 54.9 & 50.6 & 58.0 \\
\hline Stopped by the police in the last 12 months & 21.7 & 17.8 & $39.2^{* *}$ & 15.6 & 16.4 \\
\hline Ever spent a night in jail or prison & 17.4 & 16.0 & 25.1 & 17.0 & 18.2 \\
\hline Spent a night in jail or prison in last 12 months & 4.9 & 1.8 & 4.1 & 6.4 & 3.4 \\
\hline \multicolumn{6}{|l|}{ Perceptions of and feelings toward police: } \\
\hline Feel warmly toward police on 100 -point scale & 67.5 & 70.8 & $52.2^{* * *}$ & 63.0 & $75.8^{\star * *}$ \\
\hline $\begin{array}{l}\text { Percent believing Whites are treated better } \\
\text { than Blacks by the police }\end{array}$ & 60.7 & 55.7 & $80.5^{* * *}$ & 87.7 & $39.2^{* * *}$ \\
\hline $\begin{array}{l}\text { Percent believing White people are stopped } \\
\text { by the police without a good reason } \\
\text { somewhat or very often }\end{array}$ & 13.6 & 13.8 & 7.4 & 10.8 & 15.4 \\
\hline $\begin{array}{l}\text { Percent believing Black people are } \\
\text { stopped by the police without a good } \\
\text { reason somewhat or very often }\end{array}$ & 49.4 & 44.7 & $79.1^{* * *}$ & 67.2 & $33.0^{* * *}$ \\
\hline $\begin{array}{l}\text { Percent believing the police use unnecessary force } \\
\text { against Whites somewhat or very often }\end{array}$ & 12.4 & 11.1 & 13.7 & 12.7 & 13.4 \\
\hline $\begin{array}{l}\text { Percent believing the police use unnecessary force } \\
\text { against Blacks somewhat or very often }\end{array}$ & 47.0 & 40.2 & $78.6^{* * *}$ & 71.2 & $28.9^{* * *}$ \\
\hline \multicolumn{6}{|l|}{ Racial attitudes and feelings: } \\
\hline Feel warmly toward Whites on 100 -point scale & 71.0 & 74.3 & $60.6^{* * *}$ & 70.7 & 72.9 \\
\hline Feel warmly toward Blacks on 100-point scale & 66.4 & 64.9 & $79.6^{* * *}$ & 74.5 & $60.5^{\text {*** }}$ \\
\hline $\begin{array}{l}\text { Agree that Blacks should overcome prejudice } \\
\text { and work their way up without special favors } \\
\text { as other groups have }\end{array}$ & 63.6 & 69.1 & $32.6^{* * *}$ & 38.9 & $91.5^{* * *}$ \\
\hline $\begin{array}{l}\text { Disagree that slavery and discrimination have } \\
\text { created conditions that make it difficult for } \\
\text { Blacks to work their way out of the lower class }\end{array}$ & 48.8 & 56.9 & $13.3^{* * *}$ & 25.2 & $73.1^{* * *}$ \\
\hline $\begin{array}{l}\text { Disagree that Blacks have gotten less } \\
\text { than they deserve }\end{array}$ & 47.5 & 57.0 & $7.1^{* * *}$ & 21.1 & $78.1^{* * *}$ \\
\hline $\begin{array}{l}\text { Agree that if Blacks would try harder they } \\
\text { could be as well-off as Whites }\end{array}$ & 48.6 & 51.8 & $28.3^{\text {*** }}$ & 23.5 & $70.4^{* * *}$ \\
\hline
\end{tabular}

${ }^{* * *} \mathrm{p}<.001,{ }^{* *} \mathrm{p}<.01,{ }^{*} \mathrm{p}<.05$

reported a $79 \%$ chance that they would vote in the 2016 Presidential election. Table 1 also presents descriptive means and significance tests for two different sub-group comparisons: Black versus White respondents, and Trump versus Clinton supporters. 
There were no racial differences in political engagement or participation, nor were there any differences between Trump and Clinton supporters in these measures.

Political choice is also captured with two different questions. The first taps a preference for the Republican nominee, Donald Trump. Respondents were asked "regardless of whether you will vote in the Republican primary this year, which Republican candidate do you prefer?" Respondents were provided a list of the top nine candidates at that point plus the options "another Republican candidate" or "none" (about 28\% chose this option). The resulting variable is coded as 1 for those who indicated a preference for Trump and 0 for those who indicated a preference for a different Republican nominee. Of those who expressed support for some Republican candidate, about a third chose Trump, though this was a significantly more popular choice among White versus Black respondents.

The second question moves to the general election. ${ }^{7}$ Respondents were asked "If the 2016 presidential election were between Hillary Clinton for the Democrats and Donald Trump for the Republicans, would you vote for Hillary Clinton, Donald Trump, someone else, or probably not vote?" The resulting variable was coded 1 for those indicating they would vote for Trump in this case, and zero if they planned to vote for Clinton, someone else, or not vote.

The results suggest polling was close at this point in time (January 2016): around $39 \%$ expressed support for Clinton versus 37\% for Trump, with $11 \%$ voting for a third party candidate, and $14 \%$ not voting. Trump was again more popular among White relative to Black respondents. Because of the large number of potential general election matchups at this point in the primary season, respondents were randomly selected to answer only two. As a result, about $40 \%$ of the sample (487 respondents) were asked this question. With the exception of those who were randomly chosen not to answer the question about a Trump-Clinton matchup, there is no missing data for any of these questions.

\section{Criminal Justice Contact}

The survey included questions about a variety of different kinds of contact with the criminal justice system. Many, such as whether the respondent had been arrested for, charged with, or convicted of a crime were highly interrelated. We focus on two different points of contact. The first measure asked respondents whether they have been stopped and questioned by a police officer. The second asked if the respondent had spent one or more nights in jail or prison. Respondents were randomly selected to be asked these questions either in reference to the last twelve months or ever. For each model and outcome, exploratory interactions were added between a dummy variable identifying those respondents who were asked about contact in the last twelve months versus ever and each of the two measures of contact. In no case was the interaction statistically significant, suggesting that despite the different time periods, criminal justice contact was related to the outcomes in similar ways. Missing data was rare for these questions: one respondent skipped the question about police stops and two skipped the question about time in jail or prison. Black respondents were more than twice as likely to report being stopped and questioned by the police in the last year.

\section{Perceptions of the Police}

Two measures were included to reflect respondent perceptions of the police. We distinguish a basic perception of police fairness from an affective evaluation of the police, which we developed from the literature on perceived injustice and legal cynicism. The affective measure employs a "thermometer scale" question, a format common 
in ANES and other political surveys. Respondents were asked to rate their feelings toward a list of individual persons and groups on a scale ranging from 0 to 100, with 0 representing very cold and unfavorable feelings and 100 representing very warm or favorable feelings. Respondents were asked specifically how warmly or coldly they felt toward "the police." On average, respondents reported feeling modestly warm toward the police-67 on the 100-point scale. White respondents and Trump supporters reported feeling significantly more warmly toward the police than Black respondents and Clinton supporters.

The second measure taps into a very different evaluation of the police, one focused specifically on whether the police act in discriminatory ways. Specifically, the variable is captured as factor scores from a confirmatory factor analysis with three indicators. ${ }^{8}$ The first indicator is a question asking respondent, on a seven-item scale, whether they believe that "in general, the police treat Whites better than Blacks, treat Blacks better than Whites, or treat them both the same." Just over $60 \%$ of respondents reported believing that Whites were treated better than Blacks by the police. Clinton supporters and Black respondents were significantly more likely than Trump supporters and White respondents to report this-nearly $90 \%$ of Clinton supporters compared to less than $40 \%$ of Trump supporters indicated that Whites were treated better than Blacks by the police.

The second and third indicators are based on a series of questions about specific police behavior. Respondents were asked (on five-item scales) how often they think police officers stop people on the street without good reasons and how often they use more force than is necessary. They were asked each of these questions twice: once concerning how the police act when dealing with White people, and once concerning how the police act towards Black people. About half the sample, respectively, felt that Black people were stopped by the police and subject to unnecessary police force, compared to less than $15 \%$ of the sample reporting the same for the treatment of White people. Interestingly, there was widespread agreement that Whites are not often stopped without reason or subjected to unnecessary force, but Clinton supporters and Black respondents were significantly more likely to feel that Blacks experienced these kinds of police mistreatment. Two simple measures were created-one for unnecessary stops and one for unnecessary force-as the difference between perceptions of police behavior towards Blacks and Whites, with positive values representing those respondents who believed Whites were treated better and negative values reflecting those who perceived Blacks as treated better than Whites. Missing data were again rare: 1 respondent did not answer the questions about unjustified police stops, 1 skipped the general question about police discrimination, and none skipped the question about police force.

\section{Racial Attitudes}

Two measures were added to capture racial attitudes and feelings. The first is a simple measure of racial animus against Blacks relative to Whites based on the same affective thermometer scale used to capture feelings toward the police. The measure is the difference between how coldly the respondent feels toward Blacks versus Whites, with higher values indicating respondents who felt more coldly towards Blacks than Whites. The average respondent reported feeling about 5 degrees more warmly toward Whites than they did toward Blacks, with both racial groups showing in-group preferences. Clinton and Trump supporters did not differ in their feelings toward Whites, but Trump supporters felt significantly more coldly toward Blacks than did Clinton supporters. 
The second measure captures racial resentment, a dimension of "symbolic racism" widely used in prior work (Henry and Sears, 2002; Kinder 1986; Kinder and Sears, 1981; Sears 1988). The perspective suggests that because Whites view African Americans as inferior on key "Protestant Ethic" dimensions like being hard-working, they resent perceived harms resulting from these deficiencies, including African Americans getting "unfair" special access to jobs or educational opportunities. The measure is captured as factor scores from a confirmatory factor model with four indicators. A majority of the sample, nearly two-thirds, believed that Blacks should overcome prejudice and work their way up without "special favors." Around half the sample disagreed that slavery and discrimination created conditions that remained significant barriers for lowerclass Blacks, disagreed that Blacks had gotten less than they deserved, and agreed that inequalities would be solved if Blacks tried harder. However, White respondents were more likely to agree with these statements than were Black respondents, and Trump supporters were especially likely to agree with each of the racial resentment statements. Missing data were again rare: 3 respondents total skipped any of the racial resentment questions, and 4 skipped the thermometer scales against either Blacks or Whites.

\section{Political Identity and Beliefs}

We control for three measures of political sentiment when examining candidate choice: identification as conservative, identification as Republican, and belief in a limited government. One case is missing for Republican Party identification as are five for conservative ideology. Regarding preference for a limited government, 103 respondents chose the option "I haven't thought much about this." To avoid reducing the N, these cases were recoded into the middle-category-those who did not strongly agree with either statement. However, models were also run dropping these cases and did not differ substantively from the reported models.

\section{Demographic and Biographical Controls}

We control for a variety of standard demographic and biographical characteristics: gender, age, marital status, education, income, employment status, and race-ethnicity. There were no missing data for any of these questions other than income, for which 147 respondents chose not to answer. In the interest of not dropping cases, all of the missing cases were mean-replaced. However, models were also run dropping these cases and did not differ substantively from the reported models. Table 2 presents basic descriptive information on the sample for all of these control variables.

\section{Methods}

Reported effects are estimated with survey-weighted generalized linear models run using the "survey" package in R (Lumley 2014; R Core Team 2016). The four category measure indicating political engagement is treated as ordinal and modeled using an ordinal logit. The percent likelihood of voting in 2016 is treated as continuous. The measures of vote choice are dichotomous and are fit with a quasibinomial family logit link. Cases missing data on any of the outcomes or key substantive variables (contact, police, and racism) were dropped (as discussed above, missing data on these variables were infrequent), as were those for control variables with small numbers of cases missing. In total, only fourteen of the 1200 cases were dropped before the analyses. 
Table 2. Descriptive Information for the Sample on Control Measures

\section{Political ideology and identification:}

Conservative

Republican

Prefer limited government

Demographic and biographical characteristics:

Female

Age

Married/partner

Separated/divorced/widowed

At least some college

Family income above $\$ 100 \mathrm{~K}$

Unemployed

Black

Hispanic

Other race/eth.

${ }^{* * *} \mathrm{p}<.001,{ }^{* *} \mathrm{p}<.01,{ }^{*} \mathrm{p}<.05$.

The survey captures political preferences and inclinations from a point in time prior to the Presidential election itself, and as with all voting polls the respondent preferences may change and they may act differently on November 8 . The survey was conducted between January 22 and 28, 2016, prior to the major political parties' nomination of candidates. According to the poll aggregation website realclearpolitics. com, on the first day of the survey Donald Trump led the Republican field with about $35 \%$ of voters expressing a preference for him, versus about $19 \%$ for Ted Cruz, and $11 \%$ for Marco Rubio, the second and third most popular candidates at that time (Real Clear Politics 2016). Among Democrats, 51\% supported Hillary Clinton while 38\% favored Bernie Sanders (Real Clear Politics 2016). Although asked in a slightly different fashion, the question about candidate preference from the ANES survey reflects this same pattern. Among those who indicated a preference for one of the Republican candidates, the top choice with $34 \%$ of support was Donald Trump followed by Ted Cruz at $14 \%$, and then Marco Rubio at $7 \%$. Among those who expressed a preference for Democratic candidates, $45 \%$ favored Clinton versus 36\% for Sanders. In other words, although the survey occurred early in the election process, the survey data appear representative of voting preferences at that point in time.

The data are cross-sectional, and as such we cannot definitively determine the causal direction of reported relationships. It is certainly possible, for instance, that feelings of coldness toward the police or perceptions of police injustice are formed as a consequence of following political reporting or by adopting the positions of a candidate chosen for other reasons (although, in fact, we explore the possibility that racial animus rather than perceptions of the police are a motivating factor). However, given our theoretical reasons for expecting an effect on political outcomes and given the dearth of direct research on these questions, we feel there is substantial value in examining the results.

\section{Results}

The results are presented first for models predicting political engagement and participation, and then for candidate choice. 


\section{Political Engagement and Participation}

Table 3 presents two models predicting political participation and engagement. The first three columns present coefficients, standard errors, and odds ratios for an ordered logit model predicting the measure of political engagement-how closely the respondent follows politics. Among the control variables, men, older persons, single persons, and those who are employed, earn more, and have more years of education are all more likely to report that they follow politics most of the time. ${ }^{9}$ Race and ethnicity are not associated with the likelihood of following politics.

Both criminal justice contact and perceptions of the police are relevant to political engagement, although the results suggest very different substantive reasons for each of the effects. First, those who reported having been stopped by the police were substantially more likely to report that they follow politics most of the time-the odds of following politics closely are 1.8 times higher for those who have been stopped. ${ }^{10}$ On the other hand, those who have spent a night in jail or prison were substantially less likely to report following politics most of the time.

Perceptions of and affective feelings toward the police also had divergent effects on the likelihood of following politics. Those who felt more coldly toward the police were less likely to report following politics most of the time, while those who perceived the police as biased towards Blacks relative to Whites were more likely to report

Table 3. Coefficients from Models Predicting Political Engagement and Likelihood of Voting in 2016

\begin{tabular}{|c|c|c|c|c|c|}
\hline & \multicolumn{3}{|c|}{ Follow Politics } & \multicolumn{2}{|c|}{ Likely to Vote } \\
\hline & $\boldsymbol{\beta}$ & s.e. & odds & $\beta$ & s.e. \\
\hline Intercept & & & & $27.50^{* *}$ & 10.22 \\
\hline Female & $-.68^{* * *}$ & .13 & .50 & -3.50 & 2.79 \\
\hline Age & $.05^{* * *}$ & .00 & 1.06 & $.55^{* * *}$ & .09 \\
\hline Married/partner & $-.59^{* * *}$ & .16 & .56 & -6.10 & 3.61 \\
\hline Separated/divorced/widowed & $-.61^{\star *}$ & .22 & .55 & -4.06 & 4.23 \\
\hline Education & $.18^{\star * *}$ & .03 & 1.19 & $2.01^{* * *}$ & .57 \\
\hline Family Income & $.14^{* * *}$ & .02 & 1.15 & $1.41^{* *}$ & .46 \\
\hline Unemployed & $-.52^{\star \star}$ & .19 & .59 & $-15.33^{* *}$ & 5.82 \\
\hline Black & -.38 & .20 & .69 & .32 & 4.41 \\
\hline Hispanic & .23 & .20 & 1.26 & $-10.72^{*}$ & 5.22 \\
\hline Other race/eth. & .31 & .26 & 1.37 & -2.22 & 5.09 \\
\hline Stopped by police & $.59^{* * *}$ & .14 & 1.80 & $7.56^{* *}$ & 2.56 \\
\hline Jailed & $-.61^{* *}$ & .20 & .55 & $-13.90^{* *}$ & 4.94 \\
\hline Cold toward police & $-.01^{*}$ & .00 & .99 & -.09 & .06 \\
\hline Perceived police injustice & $.15^{*}$ & .08 & 1.17 & 2.17 & 1.28 \\
\hline \multicolumn{6}{|l|}{ Thresholds: } \\
\hline 1 | 2 & 1.83 & .49 & & & \\
\hline $2 \mid 3$ & 3.22 & .49 & & & \\
\hline $3 \mid 4$ & 4.85 & .51 & & & \\
\hline
\end{tabular}

${ }^{*} \mathrm{p}<.05,{ }^{* *} \mathrm{p}<.01,{ }^{* * *} \mathrm{p}<.001$ (2-tailed). $\mathrm{N}=1186$.

Follow politics employs survey-weighted ordinal logit, Likely to vote uses survey-weighted generalized linear model. 
following politics most of the time. Thus in general, a simple affective dislike of the police seems to drive people away from politics, while a perception of the police as acting in unjust ways drives greater interest. Notably, both of these effects are relatively modest.

However, as we suggested in the discussion of research questions, it is likely that people with different political orientations will be differentially motivated by these perceptions. Those who perceive the police as treating Blacks and Whites the same, or even those who believe-in the spirit of the view that anti-White bias is now more prevalent than anti-Black bias (Norton and Sommers, 2011) - that the police treat Whites worse than Blacks, may also be motivated to be more politically engaged. In this way, the same sense of injustice driving political engagement and participation may occur at both ends of the scale but for different groups. Conservative respondents may be more likely to be driven by a feeling that the police are biased against Whites while liberal respondents may be more motivated by a sense that the police are biased against Blacks. Similarly, while conservative groups have accused liberals of being motivated by anti-police feelings, pro-police messages have been common at Trump speeches and rallies (Alcindor 2016).

In fact, both measures of perceptions of the police have significant interactions with conservative identification. The top two panels of Figure 1 presents predicted values from this interaction. ${ }^{11}$ The top panel suggests that feeling more warmly toward the police is associated with an increased attention to politics, but only among those who identify as more conservative. ${ }^{12}$ Feeling warmly (or, conversely, coldly) toward the police does not seem to be associated with following politics among those who identify as more liberal. The middle panel suggest the opposite pattern for perceptions of police injustice. For those who identify as more conservative, perceptions of the police as unjust toward Whites versus Blacks do not appear to be associated with following politics. For those who identify as more liberal, however, bigger perceptions of police bias against Blacks are associated with a larger likelihood of following politics closely.

The final two columns in Table 3 present coefficients and standard errors from a weighted generalized linear model predicting the self-assessed percent likelihood that the respondent will vote in the 2016 election. Older persons, the employed, and those with more years of education and higher family income all reported a greater likelihood that they would vote in the election. Hispanic respondents tended to report a lower likelihood of voting.

Both forms of criminal justice contact appear important to the likelihood of voting, again in opposite directions. Just as being stopped by the police is associated with more political engagement, it is also associated with a higher estimated likelihood of voting-those who experienced police contact were $8 \%$ more likely to vote. The experience of having spent at least a night in jail or prison, on the other hand, appears to be more marginalizing or exclusionary, and is associated with about a $14 \%$ lower chance of voting.

Feeling coldly toward the police or perceiving the police to be racially biased, on the other, hand, are not directly significantly related to the likelihood of voting. As with political engagement, however, it may be that the effect depends on ideological identification. Interactions suggest that the feeling coldly toward the police is not strongly associated with the likelihood of voting for conservatives or liberals. However, perceptions of police bias are associated with both, and in opposite directions $(b=-2.3$, $\mathrm{p}<.001$ ). As the bottom panel of Figure 1 illustrates, for liberals, those who believe the police act in biased ways toward Blacks were more likely to say they would vote in 2016. For conservatives, it was those who believed that the police were more biased 

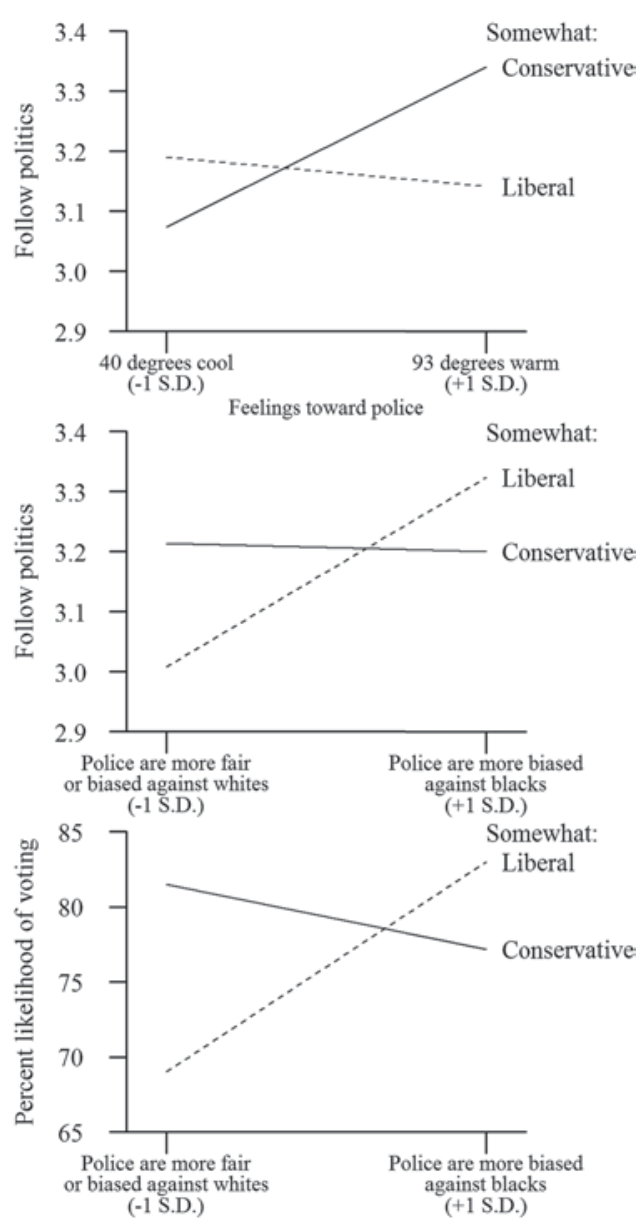

Fig. 1. Predicted levels of political engagement and participation from interaction of perceptions of police and political ideology.

against Whites who reported a higher likelihood of voting. Thus, perceptions of police injustice do appear related to people's political participation, but the direction of the effect depends on one's political ideological identification.

\section{Candidate Choice}

Table 4 presents two models of candidate choice: the choice of Trump among the Republican candidates in the primary, and the choice of Trump relative to Clinton in the general election. The first three columns present coefficients, standard errors, and odds ratios from a model of a preference for Donald Trump among the Republican presidential candidates. ${ }^{13}$ Education is among the strongest predictors of support for Trump, as those with fewer years of education were substantially more likely to express support for Trump among the Republican candidates. Relatedly, those who are unemployed were more likely to support Trump. In terms of race, Black and Hispanic voters were less likely than White voters to support Trump. All of this is consistent with the general narrative that Trump is pulling substantial support from Whites who have less education and experience greater unemployment (Thompson 2016). However, even after accounting for these associations, those who perceive greater bias against Blacks were much less likely to state support for Trump in the primary-conversely, of course, 
N Table 4. Coefficients from Models Predicting Candidate Preference (survey-weighted, quasibinomial-family logit-link)

\begin{tabular}{|c|c|c|c|c|c|c|c|c|c|c|c|c|}
\hline & \multicolumn{6}{|c|}{ Trump/ Republicans } & \multicolumn{6}{|c|}{ Trump/ Clinton } \\
\hline Intercept & .81 & .89 & & -.42 & .97 & & $-3.92^{* *}$ & 1.20 & & $-6.00^{\star * *}$ & 1.31 & .66 \\
\hline Female & .08 & .21 & 1.08 & .01 & .21 & 1.01 & -.38 & .31 & .68 & -.42 & .30 & 1.02 \\
\hline Age & .00 & .01 & 1.00 & .00 & .01 & 1.00 & $.03^{*}$ & .01 & 1.03 & $.02^{*}$ & .01 & 1.69 \\
\hline Married/partner & .40 & .29 & 1.49 & .27 & .29 & 1.32 & .67 & .38 & 1.95 & .52 & .39 & 1.13 \\
\hline Family Income & -.05 & .04 & .95 & -.04 & .04 & .96 & -.06 & .06 & .94 & -.04 & .06 & .57 \\
\hline Unemployed & $.87^{*}$ & .37 & 2.38 & $.86^{*}$ & .36 & 2.37 & -.51 & .42 & .60 & -.56 & .42 & 2.08 \\
\hline Black & $-1.19^{*}$ & .53 & .31 & -.58 & .52 & .56 & -.02 & .63 & .98 & .73 & .71 & .78 \\
\hline Hispanic & $-1.03^{*}$ & .45 & .36 & $-.94^{*}$ & .43 & .39 & -.40 & .54 & .67 & -.25 & .49 & 2.61 \\
\hline Other race/eth. & -.54 & .43 & .58 & -.45 & .42 & .64 & .66 & .53 & 1.93 & .96 & .57 & 1.16 \\
\hline Conservative & .01 & .08 & 1.01 & -.02 & .09 & .98 & .17 & .11 & 1.19 & .15 & .12 & 1.58 \\
\hline Stopped by police & -.36 & .21 & .70 & -.34 & .22 & .71 & -.53 & .36 & .59 & -.63 & .38 & 1.83 \\
\hline Jailed & .46 & .36 & 1.58 & .28 & .34 & 1.32 & .40 & .54 & 1.49 & .60 & .57 & 1.00 \\
\hline Cold toward police & .00 & .00 & 1.00 & .00 & .00 & 1.00 & .00 & .01 & 1.00 & .00 & .01 & .46 \\
\hline Perceived police injustice & $-.38^{\star *}$ & .15 & .68 & -.17 & .17 & .84 & $-.98^{* * *}$ & .22 & .37 & $-.77^{* *}$ & .23 & .66 \\
\hline $\mathrm{N}$ & & 837 & & & 837 & & & 480 & & & 480 & \\
\hline
\end{tabular}

${ }^{* * *} \mathrm{p}<.001,{ }^{* *} \mathrm{p}<.01,{ }^{*} \mathrm{p}<.05$ 
this means those who believe the police may be biased against Whites were more likely to support Trump. Notably, neither contact with the criminal justice system nor more affective negative feelings toward the police appear to be relevant to support for Trump.

The next three columns in Table 4 present a second model for Trump support in the primary, this time adding two measures of racial attitudes and feelings toward Blacks. Explicit animus toward Blacks - those who openly admit to feeling more warmly toward Whites than Blacks - is strongly and positively associated with support for Trump. Similarly, racial resentment of Blacks is also strongly and positively related to a preference for Trump. Interestingly, including these measures of racial attitudes have two important impacts on other estimates in the model. First, the size of the estimate for the difference between Black and White respondents is cut in half and drops below conventional significance. In other words, racial animus and racial resentment appear important to explaining the different preferences among White and Black voters in the Republican primary. Second, the estimate for the effect of perceived police injustice is also cut nearly in half and drops below conventional significance. In other words, if racial attitudes were ignored, it would appear that people's perceptions of police injustice was important in distinguishing Trump supporters from those who support other candidates. However, the full results suggest such perceptions may be acting as a proxy for racial attitudes among these voters. In other words, when choosing among the Republican candidates, perceptions of the police were less important than attitudes toward Blacks.

The third set of columns switches the focus to the general election, contrasting those who indicate they would likely vote for Donald Trump in a general election against Hillary Clinton versus those who would vote for Clinton, a third-party candidate, or no one. ${ }^{14}$ Not surprisingly, partisanship is an important factor in the general election, with those who identify most with the Republican Party expressing the strongest support for Donald Trump in a match-up with Hillary Clinton. Relatedly, "small government" advocates are more likely to support Donald Trump—an interesting finding given that Donald Trump, in contrast to previous Republican candidates, has not made "small government" a campaign issue and has in fact proposed significant government expansions (Appelbaum 2016; French 2016). However, even after political party identification is controlled for, perceptions of the police as biased against Blacks is strongly and negatively associated with opposition to Donald Trump. Once again, neither contact with the criminal justice system nor more affective negative feelings toward the police appear to be relevant to support for Trump.

The final set of models adds the two measures of racial attitudes. Although explicit animus is not significantly associated with candidate choice in the general election, those respondents who scored high on the racial resentment measure were substantially more likely to express support for Donald Trump. Including this measure results in a substantial drop in the direct effect of a preference for limited government, complementing prior work suggesting that individualistic or anti-big government ideological positions often serve as a mask for racial resentments (Bobo et al., 1997; Bonilla-Silva 2010; Kinder and Sears,1981; Jackman and Muha, 1984). There is also a modest decrease in the direct effect of perceptions of police injustice, though, unlike the primary model, perceptions of police injustice remain an important predictor of opposition to Donald Trump in the general election.

\section{DISCUSSION AND CONCLUSION}

During the Civil Rights era, which was a particularly turbulent moment in American political history, intersecting issues of race, crime, policing, and justice had great salience 
for political behavior. Specifically, issues of crime, justice, and the police became important sites for conflict about the relative status of racial groups. Outrage over the unfair treatment of Black citizens by the police set off massive protests across the country, ultimately contributing to the passage of several landmark pieces of civil rights legislation. At the same time, White politicians reframed these protests as criminal to delegitimize them, used law and order rhetoric as a signal to rally White voters uncomfortable with the changes posed by the Civil Rights Movement, and simultaneously used law enforcement officers to try to suppress political activity by civil rights protestors.

Thus, claims of unjust treatment at the hands of the police were used to motivate action to attempt to address problems of racial inequality. On the other side, "law and order" rhetoric as well as the actual institutions of the criminal justice system served as tools in efforts to maintain White superiority. These tools play a critical role in the new racial logic justifying White privilege, one that de-emphasizes group distinctions and instead favors individualistic explanations for inequalities (Bobo et al., 1997; Bonilla-Silva 2010; Jackman and Muha, 1984). In this model, the "law and order" rhetoric serves as an implicit racially-coded appeal to rally those concerned about challenges to the racial order without mentioning race or legitimizing the importance of the racial structure (López 2014; Mendelberg 2001). Contemporary criminal justice institutions also serve an important role, mirroring some of the functions of older systems of racial confinement and subjugation like slavery and the Jim Crow system, but without the overtly-stated racial motivations and goals of those institutions (Alexander 2010; Wacquant 2005).

The findings presented in this paper reveal the continued relevance of the intersection of race, crime, justice, and policing to American political behavior. Just as in that earlier era, though, the relevance is far from simple or one-dimensional. The results suggest, for instance, that the impact of contact with the criminal justice system depends on the form and punitiveness of contact. While incarceration is a severe, marginalizing, and exclusionary form of contact that tends to drive citizens away from political engagement and participation, the experience of police stops and questioning appears to do the opposite, by motivating citizens to become politically engaged and to vote.

We further find perceptions of police injustice to be an important factor both in political participation and candidate choice. The impact of these perceptions, however, differs along lines of political ideology. We find that perceptions of police injustice against Blacks motivate liberals to vote, and to vote for the Democratic presidential candidate, Hillary Clinton. Perceptions of the police as fair or even biased against Whites, on the other hand, motivates turnout among conservatives and greater support for the Republican candidate, Donald Trump.

Notably, we find that perceptions of the police are not simply expressions of affective evaluations of the police. Moreover, we find that affect is not significantly associated with candidate choice, or, for the most part, with turnout. For example, feeling warmly toward the police only motivated political engagement among conservatives. Alternatively, we found no effect of feeling warmly or coldly toward the police among liberals.

The simplest and most general conclusion from our analysis is that both criminal justice contact and perceptions of police injustice matter for political behavior in 2016. This indicates that researchers in political science, political sociology, and political criminology should take these race, crime, justice, and policing issues seriously when trying to understand contemporary political behavior.

One finding is particularly troubling. Consistent with Lerman and Weaver (2014), we find that certain forms of contact with the criminal justice system marginalize and 
exclude citizens from political engagement. Those who had spent a night in jail or prison were much less likely to report following politics and rated their likelihood of voting in 2016 as much lower. This complements and extends work on the most direct effect of incarceration-felon disenfranchisement-in its critique of the corrosively antidemocratic impact of the carceral state (Manza and Uggen, 2006; Weaver and Lerman, 2010).

Finally, the influence of perceptions of police injustice has both encouraging and worrisome implications. On the one hand, consistent with the broader narrative from the Civil Rights era, perceptions of the police as disproportionately mistreating Black citizens motivates political engagement, participation, and support for the presidential candidate explicitly proposing police reforms. On the other hand, perceptions of the police as unbiased or as biased against Whites motivates engagement, participation and support for the candidate who has been unconditionally supportive of police and antagonistic towards the accountability concerns of the Black Lives Matter movement. We have found evidence that perceptions of police injustice in the latter group may be a proxy for anti-Black sentiment.

For fifty years, politicians have used racialized allusions to crime and disorder in order to prey on voters' fears, secure electoral gains, and enact punitive criminal justice policies. The same types of conflicts between police and communities of color that sparked the most controversial and polarizing events during the Civil Rights Movement are occurring once again across the country. Despite recent progress toward bipartisan criminal justice reform in congress and numerous state legislatures, this study provides further evidence that the same racialized tensions that polarized the electorate in the 1960s are still shaping national politics today.

Corresponding author: Kevin M. Drakulich, School of Criminology and Criminal Justice, Northeastern University, Boston, MA, 02130. E-mail: k.drakulich@northeastern.edu

\section{NOTES}

1. The only exception was Louisiana in 1956.

2. The one major exception is 1976, which saw the election of the of the first president from a deep south state since the Civil War. Louisiana and Georgia also voted for the next southern-born President in 1992 and Louisiana did again in 1996.

3. Notably, these numbers come from the NYPD and likely undercount police stops, as officers may be less likely to make a record of a stop that did not produce anything to justify an arrest. Source: New York Civil Liberties Union, http://www.nyclu.org/content/stop-and-frisk-data.

4. Before weighting the data, the average respondent was forty-eight years old, and the sample was roughly $11 \%$ Black, $9 \%$ Hispanic, and $52 \%$ female.

5. The sample was selected from the YouGov panel by sample matching, using prior estimates of the U.S. population along the lines of gender, age, race, education, voter registration and turnout status, as well as politics and party identification. The survey was conducted in English. Additional information about the study can be found at http://www.electionstudies.org/ studypages/anes_pilot_2016/anes_pilot_2016.htm

6. For ease of interpretation, ordinal variables are summarized as dichotomous-specifically the percent that fall on either side of key thresholds-in Tables 1 and 2 but left as ordinal in the full regressions.

7. Exploratory analyses suggested that criminal justice contact and perceptions of the police were less relevant to preferences for Clinton versus Sanders as the Democratic nominee.

8. Latent factor scores were derived from a confirmatory factor model which treats each item as ordinal and used a weighted least squares estimator. The model created factor scores both for perceptions of police injustice and for the racial resentment scale discussed below. The model fit reasonably well (RMSEA: $0 ; \chi^{2}=.044 ; \mathrm{df}=10 ; \mathrm{p}=.001$ ). A simple index 
(alpha reliability of .84) was also considered, and showed substantively similar results to those reported here.

9. While political choice is expected to be a product of political identification and racial prejudice, political participation was not expected to be associated with these outcomes and indeed, the exploratory models suggested no direct effects of politics or prejudice on either outcome (although, as noted below, conditional effects do exist).

10. A note on interpretation: an ordered logit model assumes that regression coefficients remain the same as one moves to different levels in the response, so the odds ratio represents the odds of being in any higher level of concern or worry versus the lower levels (thus it simultaneously represents, for instance, the difference between the most politically-engaged category and all three lower answers but also the difference between the top three most engaged answers and the least engaged answer). Diagnostics revealed no evidence that the proportional odds assumption was violated.

11. For ease of interpretation, we present results from a model which treats political engagement as linear, although the interaction terms were also significant in the ordered logit models $(b=-.003, p<.05$ for feeling cold toward police and $b=-.12, p<.01$ for perceptions of police injustice). We also reverse the direction of affect toward the police to ease interpretation.

12. The political ideology scale ranges from extremely liberal (1) to extremely conservative (7). The predicted results shown are for those identifying as "somewhat" liberal (2) versus "somewhat" conservative (6).

13. Those who preferred none of the Republican candidates are omitted from this analysis to emphasize the choice among Republican candidates.

14. Operationalizing this variable as Hillary Clinton versus Trump, third-party-candidate, and non-voters, or as Trump versus Clinton with third-party and non-voters dropped produces substantively similar results.

\section{REFERENCES}

Alcindor, Yamiche (2016). Trump, Rallying White Crowd for Police, Accuses Democrats of Exploiting Blacks. The New York Times, August 16. <http://www.nytimes.com/2016/08/17/ us/politics/donald-trump-rally-is-called-chance-to-show-support-for-police.html?_r=0> (accessed October 27, 2016).

Alexander, Michelle (2010). The New Fim Crow: Mass Incarceration in the Age of Colorblindness. New York: The New Press.

American National Election Studies (ANES) (2016). The ANES 2016 Pilot Study [dataset]. Stanford University and the University of Michigan [producers].

Anderson, Elijah (1999). Code of the Street: Decency, Violence, and the Moral Life of the Inner City. New York: W. W. Norton.

Appelbaum, Yoni (2016). Trump Wants to Make Government Huge Again. The Atlantic, March 13. <http://www.theatlantic.com/politics/archive/2016/03/trump-government-ethnocentrism/ 473538/> (accessed October 27, 2016).

Beckett, Katherine (1997). Making Crime Pay: Law and Order in Contemporary American Politics. New York: Oxford University Press.

Beckett, Katherine, and Theodore Sasson (2004). The Politics of Injustice: Crime and Punishment in America, 2nd edition. Thousand Oaks, CA: Pine Forge Press.

Behrens, Angela, Christopher Uggen, and Jeff Manza (2003). Ballot Manipulation and the 'Menace of Negro Domination': Racial Threat and Felon Disenfranchisement in the United States, 1850-2002. American Fournal of Sociology, 109: 559-605.

Beinart, Peter (2015). Hillary Clinton and the Tragic Politics of Crime. The Atlantic, May 1.

Benford, Robert D. (1993). "You Could be the Hundredth Monkey": Collective Action Frames and Vocabularies of Motive Within the Nuclear Disarmament Movement. Sociological Quarterly, 34: 195-216.

Benford, Robert D., and David A. Snow (2000). Framing Processes and Social Movements: An Overview and Assessment. Annual Review of Sociology, 26: 611-639.

Berger, J. M. (2016). Nazis vs. ISIS on Twitter: A comparative Study of White Nationalist and ISIS Online Social Media Networks. George Washington University Program on Extremism Report. <https://cchs.gwu.edu/sites/cchs.gwu.edu/files/downloads/Nazis\%20v.\%20ISIS\%20Final_0. pdf> (accessed October 27, 2016). 
Blumer, Herbert (1958). Race Prejudice as a Sense of Group Position. Pacific Sociological Review, $1: 3-7$.

Bobo, Lawrence D. (2004). Inequalities that Endure? Racial Ideology, American Politics, and the Peculiar Role of Social Science. In Maria Krysan and Amanda E. Lewis (Eds.), Changing Terrain of Race and Ethnicity, pp. 13-42. New York: Russell Sage Foundation.

Bobo, Lawrence D., and Devon Johnson (2004). A Taste for Punishment: Black and White Americans' Views on the Death Penalty and the War on Drugs. Du Bois Review: Social Science Research on Race, 1: 151-80.

Bobo, Lawrence D., and James R. Kluegel (1997). Status, Ideology, and Dimensions of Whites' Racial Beliefs and Attitudes: Progress and Stagnation. In Steven A. Tuch and Jack K. Martin (Eds.), Racial Attitudes in the 1990s: Continuity and Change, pp. 93-120. Westport, CT: Praeger.

Bobo, Lawrence D., and Ryan A. Smith (1998). From Jim Crow Racism to Laissez-Faire Racism: The Transformation of Racial Attitudes. In Wendy F. Katkin, Ned Landsman, and Andrea Tyree (Eds.), Beyond Pluralism: The Conception of Groups and Group Identities in America, pp. 182-220. Chicago, IL: University of Illinois Press.

Bobo, Lawrence D., and Victor Thompson (2006). Unfair by Design: The War on Drugs, Race, and the Legitimacy of the Criminal Justice System. Social Research: An International Quarterly, 73: 445-472.

Bobo, Lawrence D., James R. Kluegel, and Ryan A. Smith (1997). Laissez-Faire Racism: The Crystallization of a Kinder, Gentler, Antiblack Ideology. In Steven A. Tuch and Jach K. Martin (Eds.), Racial Attitudes in the 1990s: Continuity and Change, pp. 15-41. Westport, CT: Praeger.

Bonilla-Silva, Eduardo (2010). Racism without Racists: Color-Blind Racism and the Persistence of Racial Inequality in the United States. $3^{\text {rd }}$ Ed. New York: Rowman \& Littlefield Publishers.

Bouie, Jamelle (2015). Hillary Clinton's Impressive Criminal Justice Speech. Slate.com, April 30. <http://www.slate.com/articles/news_and_politics/politics/2015/04/hillary_clinton_s_ impressive_criminal_justice_speech_the_democratic_front.html> (accessed October 27, 2016).

Branch, Taylor (1998). Pillar of Fire: America during the King Years 1963-65. New York: Simon and Schuster Paperbacks.

Brennan, Geoffrey, and Alan Hamlin (1998). Expressive Voting and Electoral Equilibrium. Public Choice, 95: 149-175.

Brunson, Rod K., and Ronald Weitzer (2009). Police Relations with Black and White Youths in Different Urban Neighborhoods. Urban Affairs Review, 44: 858-885.

Campbell, Colin (2015). Donald Trump Trashes Black Lives Matter: "I think they're trouble". Business Insider, September 9. <http://www.businessinsider.com/donald-trump-black-livesmatter-2015-9> (accessed October 27, 2016).

Capehart, Jonathan (2016). Hillary Clinton on 'Superpredator' Remarks: "I Shouldn't Have Used Those Words." Washington Post, February 25. <https://www.washingtonpost.com/ blogs/post-partisan/wp/2016/02/25/hillary-clinton-responds-to-activist-who-demandedapology-for-superpredator-remarks/> (accessed October 27, 2016).

Carmines, Edward G., and James A. Stimson (1989). Issue Evolution: Race and the Transformation of American Politics. Princeton, NJ: Princeton University Press.

Carr, Patrick J., Laura Napolitano, and Jessica Keating (2007). We Never Call the Cops and Here Is Why: A Qualitative Examination of Legal Cynicism in Three Philadelphia Neighborhoods. Criminology, 45: 445-480.

Clear, Todd R. (2007). Imprisoning Communities: How Mass Incarceration Makes Disadvantaged Neighborhoods Worse. New York: Oxford University Press.

Clear, Todd R., and Natasha A. Frost (2014). The Punishment Imperative: The Rise and Failure of Mass Incarceration in America. New York: New York University Press.

Confessore, Nicholas (2016). For Whites Sensing Decline, Donald Trump Unleashes Words of Resistance. The New York Times, July 13. <http://www.nytimes.com/2016/07/14/us/politics/ donald-trump-white-identity.html> (accessed October 27, 2016).

de Tocqueville, Alexis (2004[1840]). Democracy in America. Translated by Arthur Goldhammer. New York: Library of America.

Desmond, Matthew, Andrew V. Papachristos, and David S. Kirk (2016). Police Violence and Citizens Crime Reporting in the Black Community. American Sociological Review, 81(5): 857-876.

Diamond, Jeremy (2016). Trump: Black Lives Matter has helped instigate police killings. CNN. com, July 19. < http://www.cnn.com/2016/07/18/politics/donald-trump-black-lives-matter/> (accessed October 27, 2016). 


\section{Kevin Drakulich et al.}

Drakulich, Kevin M. (2015a). Explicit and Hidden Racial Bias in the Framing of Social Problems. Social Problems, 62(3): 391-418.

Drakulich, Kevin M. (2015b). The Hidden Role of Racial Bias in Support for Policies Related to Inequality and Crime. Punishment \& Society, 17(5): 541-574.

Edsall, Thomas Byrne, and Mary D. Edsall (1991). When the Official Subject Is Presidential Politics, Taxes, Welfare, Crime, Rights, or Values... The Real Subject Is Race. Atlantic Monthly, $267,53-86$.

Eligon, J. (2015). Ferguson Elects 2 Blacks but Snubs Protest Slate. New York Times, April 7.

Fagan, Jeffrey, and Garth Davies (2000). Street Stops and Broken Windows: Terry, Race, and Disorder in New York City. Fordham Urban Law Fournal, 28: 457-504.

Feagin, Joe R. (2009). The White Racial Frame: Centuries of Racial Framing and Counter-Framing. New York: Routledge.

Fields, Gary (2016). Trump Says Crime Near Records, but Data Show Murders Well Below '90s Highs. The Wall Street fournal, August 29. <http://blogs.wsj.com/washwire/2016/08/29/ trump-says-crime-near-records-but-data-show-murders-well-below-90s-highs/> (accessed October 27, 2016).

French, David (2016). Trump's Speech Makes It Official: It's Democrat v. Democrat in 2016. National Review, July 22. <http://www.nationalreview.com/article/438234/donald-trumpconvention-speech-small-government-conservatism-dead> (accessed October 27, 2016).

Fryer, Roland G., Jr. (2016). An Empirical Analysis of Racial Differences in Police Use of Force. Working paper issued in July 2016. <http://www.nber.org/papers/w22399> (accessed October 27, 2016).

Gitlin, Todd (1980). The Whole World Is Watching: Mass Media in the Making and Unmaking of the New Left. Berkeley, CA: University of California Press.

Gau, Jacinta M., and Rod K. Brunson (2010). Procedural Justice and Order Maintenance Policing: A Study of Inner-City Young Men's Perceptions of Police Legitimacy. Fustice Quarterly, 27: $255-279$.

Goffman, Erving (1974). Frame Analysis: An Essay on the Organization of Experience. Cambridge, MA: Harvard University Press.

Grawert, Ames C. (2016). The Overlooked Promise in Hillary Clinton's Speech: A Call for Criminal Justice Reform. The Marshall Project, July 31. <https://www.themarshallproject. org/2016/07/31/the-overlooked-promise-in-hillary-clinton-s-speech\#.PQIJ7qNmU> (accessed October 27, 2016).

Greenberg, Jon (2015). Trump's Pants on Fire Tweet that Blacks Killed 81\% of White Homicide Victims. Politifact, November 23. <http://www.politifact.com/truth-o-meter/statements/2015/ nov/23/donald-trump/trump-tweet-blacks-white-homicide-victims/> (accessed October 27, 2016).

Greer, Scott (2015). Liberals Hate Police but Love Police States. The Daily Caller, October 8. $<$ http://dailycaller.com/2015/10/08/liberals-hate-police-but-love-police-states/> (accessed October 27, 2016).

Hagan, John (2010). Who Are the Criminals? The Politics of Crime Policy from the Age of Reagan to the Age of Roosevelt. Princeton, NJ: Princeton University Press.

Hagan, John, and Celesta Albonetti (1982). Race, Class, and the Perception of Criminal Injustice in America. American fournal of Sociology, 88: 329-355.

Hagan, John, Carla Shedd, and Monique R. Payne (2005). Race, Ethnicity, and Youth Perceptions of Criminal Injustice. American Sociological Review, 70: 381-407.

Hagan, John, Joshua Kaiser, and Anna Hanson (2016). The Theory of Legal Cynicism and Sunni Insurgent Violence in Post-Invasion Iraq. American Sociological Review, 81: 316-346.

Hampton, Henry, and Steve Fayer (1990). Voices of Freedom: An Oral History of the Civil Rights Movement from the 1950s through the 1980s. New York: Bantam.

Henry, P. J., and David O. Sears (2002). The Symbolic Racism 2000 Scale. Political Psychology, 23: 253-283.

Hurst, Yolander G., James Frank, and Sandra Lee Browning (2000). The Attitudes of Juveniles toward the Police. Policing: An International fournal of Police Strategies \& Management, 23: $37-53$.

Jackman, Mary R., and Michael J. Muha (1984). Education and Intergroup Attitudes: Moral Enlightenment, Superficial Democratic Commitment, or Ideological Refinement? American Sociological Review, 49: 751-69.

Johnson, Devon (2001). Punitive Attitudes on Crime: Economic Insecurity, Racial Prejudice, or Both? Sociological Focus, 34: 33-54. 
Johnson, Devon (2008). Racial Prejudice, Perceived Injustice, and the Black-White Gap in Punitive Attitudes. Fournal of Criminal fustice, 36: 198-206.

Johnson, Devon (2009). Anger about Crime and Support for Punitive Criminal Justice Policies. Punishment \& Society, 11: 51-66.

Johnson, Jenna, and Mary Jordan (2015). Trump on Rally Protester: "Maybe he should have been roughed up." The Washington Post, November 22.

Kane, Robert J. (2002). The Social Ecology of Police Misconduct. Criminology, 40: 867-896.

Kinder, Donald R. (1986). The Continuing American Dilemma: White Resistance to Racial Change 40 Years after Myrdal. Fournal of Social Issues, 42: 151-71.

Kinder, Donald R., and David O. Sears (1981). Prejudice and Politics: Symbolic Racism Versus Racial Threats to the Good Life. Fournal of Personality and Social Psychology, 40: 414-431.

Kirk, David S., and Andrew Papachristos (2011). Cultural Mechanisms and the Persistence of Neighborhood Violence. American fournal of Sociology, 116: 1190-1233.

Kirk, David S., and Mauri Matsuda (2011). Legal Cynicism, Collective Efficacy, and the Ecology of Arrest. Criminology, 49: 443-472.

Klinker, Philip (2016). The Easiest Way to Guess if Someone Supports Trump? Ask if Obama is a Muslim. Vox.com, June 2. <http://www.vox.com/2016/6/2/11833548/donald-trump-supportrace-religion-economy (accessed October 27, 2016).

Landy, Marc (1993). Public Policy and Citizenship, in Helen Ingram and Steven Rathgeb Smith (Eds.), Public Policy for Democracy, pp. 19-44. Washington, DC: The Brookings Institute.

Lerman, Amy E., and Vesla M. Weaver (2014). Arresting Citizenship: The Democratic Consequences of American Crime Control. Chicago, IL: University of Chicago Press.

Levy-Pounds, Nekima (2013). Par for the Course?: Exploring the Impacts of Incarceration and Marginalization on Poor Black Men in the U.S. Fournal of Law and Society, 14: 29-63.

Lipsky, Michael (1980). Street-Level Bureaucracy. New York: Russell Sage Foundation.

López, Ian Haney (2014). Dog Whistle Politics: How Coded Racial Appeals Have Reinvented Racism and Wrecked the Middle Class. Oxford, UK: Oxford University Press.

Lumley, Thomas (2014). Survey: Analysis of Complex Survey Samples. R package version 3.30.

Manza, Jeff, and Christopher Uggen (2006). Locked Out: Felon Disenfranchisement and American Democracy. New York: Oxford University Press.

Mastrofski, Stephen, Michael Reisig, and John D. McClusky (2002). Police Disrespect Toward the Public: An Encounter-Based Analysis. Criminology, 40: 519-551.

Matsueda, Ross L., and Kevin M. Drakulich (2009). Perceptions of Criminal Injustice, Symbolic Racism, and Racial Politics. The Annals of the American Academy of Political and Social Science, 623: 163-178.

Matsueda, Ross L., Kevin M. Drakulich, John Hagan, Lauren J. Krivo, and Ruth D. Peterson (2011). Crime, Perceptions of Criminal Injustice, and Electoral Politics. In John Aldrich and Kathleen M. McGraw (Eds.), Improving Public Opinion Surveys: Interdisciplinary Innovation and the American National Election Studies, pp. 323-341. Princeton, NJ: Princeton University Press.

Mauer, Marc, and Meda Chesney-Lind (Eds.) (2002). Invisible Punishment: The Collateral Consequences of Mass Imprisonment. New York: The New Press.

McAdam, Doug (1988). Freedom Summer. Oxford, UK: Oxford University Press.

McElwee, Sean, and Jason McDaniel (2016). Yes, Trump's Biggest Asset is Racism: Why Bigotry (Not the Economy) is the Biggest Factor Driving his Rise." Salon.com, March 22. <http:// www.salon.com/2016/03/22/yes_trumps_secret_weapon_is_racism_why_bigotry_not_the_ economy_is_the_biggest_factor_driving_his_rise/> (accessed October 27, 2016).

Mendelberg, Tali (1997). Executing Hortons: Racial Crime in the 1988 Presidential Campaign. Public Opinion Quarterly, 61: 134-157.

Mendelberg, Tali (2001). The Race Card: Campaign Strategy, Implicit Messages, and the Norm of Equality. Princeton, NJ: Princeton University Press.

National Research Council (2014). The Growth of Incarceration in the United States: Exploring Causes and Consequences. Washington, DC: The National Academies Press.

Norton, Michael I., and Samuel R. Sommers (2011). Whites See Racism as a Zero-Sum Game that They Are Now Losing. Perspectives on Psychological Science, 6: 215-18.

Nuzzi, Olivia (2016). Trump: Big on Law and Order, Silent on Racism. The Daily Beast, July 11. $<$ http://www.thedailybeast.com/articles/2016/07/11/trump-big-on-law-and-order-silenton-racism.html> (accessed October 27, 2016).

Peffley, Mark A., and Jon Hurwitz (2010). Fustice in America: The Separate Realities of Blacks and Whites. New York: Cambridge University Press.

Pettit, Becky (2012). Invisible Men: Mass Incarceration and the Myth of Black Progress. New York: Russell Sage Foundation. 
Pettit, Becky, and Bruce Western (2004). Mass Imprisonment and the Life Course: Race and Class Inequality in U.S. Incarceration. American Sociological Review, 69: 151-169.

R Core Team (2016). R: A Language and Environment for Statistical Computing. R Foundation for Statistical Computing, Vienna, Austria.

Real Clear Politics (2016). 2016 Republican Presidential Nomination. <http://www.realclearpolitics. com/epolls/2016/president/us/2016_republican_presidential_nomination-3823.html> (accessed October 27, 2016).

Rios, Victor M. (2011). Punished: Policing the Lives of Black and Latino Boys. New York: NYU Press.

Rosich, K. J. (2007). Race, Ethnicity, and the Criminal fustice System. Washington, DC: American Sociological Association.

Sampson, Robert J., and Dawn Jeglum Bartusch (1998). Legal Cynicism and (Subcultural?) Tolerance of Deviance: The Neighborhood Context of Racial Difference. Law \& Society Review, 32: 777-804.

Schuman, Howard, Charlotte Steeh, Lawrence D. Bobo, and Maria Krysan (1997). Racial Attitudes in America: Trends and Interpretations. Cambridge, MA: Harvard University Press.

Sears, David O. (1988). Symbolic racism. In Phyllis A. Katz and Dalmus A. Taylor (Eds.), Eliminating Racism: Profiles in Controversy, pp. 53-84. New York: Plenum Press.

Silverman, Eli B., and Jo-Ann Della-Giustina (2001). Urban Policing and the Fear of Crime. Urban Studies, 38: 941-957.

Skogan, Wesley G. (2005). Citizen Satisfaction with Police Encounters. Police Quarterly, 8: 298-321.

Smith, Douglas (1986). The Neighborhood Context of Police Behavior. In Albert Reiss and Michael Tonry (Eds.), Crime and fustice, Vol. 8, pp. 313-341. Chicago, IL: University of Chicago Press.

Snow, David A., and Robert D. Benford (1992). Master Frames and Cycles of Protest. In Aldon D. Morris and Carol McClurg Mueller (Eds.), Frontiers of Social Movement Theory, pp. 133-155. New Haven, CT: Yale University Press.

Soss, Joe (2005). Making Clients and Citizens: Welfare Policy as a Source of Status, Belief, and Action. In Anne L. Schneider and Helen M. Ingram (Eds.), Deserving and Entitled: Social Constructions and Public Policy, pp. 291-328. Albany, NY: State University of New York Press.

Soss, Joe, Laura Langbein, and Alan R. Metelko (2003). Why Do White Americans Support the Death Penalty? Fournal of Politics, 65: 397-421.

Stranahan, Lee (2016). Donald Trump's Praise for Cops Angers Left, 'Black Lives Matter' Activists. Breitbart.com, February 7. <http://www.breitbart.com/big-government/2016/02/07/2962818/> (accessed October 27, 2016).

Stoltzfoos, Rachel (2015). Here Is Marco Rubio's Brilliant Response to Black Lives Matter. DailyCaller.com, October 1. <http://dailycaller.com/2015/10/01/here-is-marco-rubios-brilliantresponse-to-black-lives-matter/\#ixzz4JmuziBDd> (accessed October 27, 2016).

Terrill, William, and Michael D. Reisig (2003). Neighborhood Context and Use of Police Force. Fournal of Research in Crime and Delinquency, 40: 291-321.

Tesler, Michael (2016). Post-Racial or Most-Racial? Race and Politics in the Obama Era. Chicago, IL: University of Chicago Press.

Thompson, Derek (2016). Who Are Donald Trump's Supporters, Really? The Atlantic, March 1. <http://www.theatlantic.com/politics/archive/2016/03/who-are-donald-trumps-supportersreally/471714/> (accessed October 27, 2016).

Tonry, Michael (2011). Punishing Race: A Continuing American Dilemma. New York: Oxford University Press.

Travis, Jeremy (2002). Invisible Punishment: An Instrument of Social Exclusion. In Meda Chesney-Lind and Marc Mauer (Eds.), Invisible Punishment: The Collateral Consequences of Mass Imprisonment, pp. 15-36. New York: The Free Press.

Turner, Ralph H. (1969). The Theme of Contemporary Social Movements. The British fournal of Sociology, 20: 390-405.

Tyler, Tom R., and Cheryl J. Waslak (2004). Profiling and Police Legitimacy: Procedural Justice, Attributions of Motive, And Acceptance of Police Authority. Criminology, 42: 253-281.

Uggen, Christopher, and Jeff Manza (2002). Democratic Contraction? The Political Consequences of Felon Disenfranchisement in the United States. American Sociological Review, 67: 777-803.

Unnever, James D., and Francis T. Cullen (2007). The Racial Divide in Support for the Death Penalty: Does White Racism Matter? Social Forces, 85: 1281-1301.

Unnever, James D., and Francis T. Cullen (2010). Racial-Ethnic Intolerance and Support for Capital Punishment: A Cross-National Comparison. Criminology, 48: 831-864. 
Wacquant, Loïc (2005). The Great Penal Leap Backward: Incarceration in America from Nixon to Clinton. In John Pratt, David Brown, Mark Brown, Simon Hallsworth, and Wayne Morrison (Eds.), In The New Punitiveness: Trends, Theories, Perspectives, pp. 3-26. Devon, UK: Willan.

Waddington, P. A. J., and Quentin Braddock (1991). Guardians or Bullies? Perceptions of the Police amongst Adolescent Black, White and Asian Boys. Policing and Society, 2: 31-45.

Weaver, Vesla M. (2007). Frontlash: Race and the Development of Punitive Crime Policy. Studies in American Political Development, 21: 230-265.

Weaver, Vesla M., and Amy E. Lerman (2010). Political Consequences of the Carceral State. American Political Science Review, 104: 817-833.

Weitzer, Ronald, and Steven A. Tuch (1999). Race, Class, and Perceptions of Discrimination by The Police. Crime and Delinquency, 45: 494-507.

Weitzer, Ronald, and Steven A. Tuch (2002). Perceptions of Racial Profiling: Race, Class, and Personal Experience. Criminology, 40: 435-456.

Weitzer, Ronald, and Steven A. Tuch (2004a). Reforming the Police: Racial Differences in Public Support for Change. Criminology, 42: 391-416.

Weitzer, Ronald, and Steven A. Tuch (2004b). Race and Perceptions of Police Misconduct. Social Problems, 51: 305-325.

Weitzer, Ronald, and Steven A. Tuch (2005). Racially Biased Policing: Determinants of Citizen Perceptions. Social Forces, 83: 1009-1030.

Western, Bruce (2006). Punishment and Inequality in America. New York: Russell Sage Foundation.

Whack, Errin Haines (2016). Groups Affiliated with Black Lives Matter Release Agenda. Associated Press, August 1. <http://bigstory.ap.org/article/41484b9f10884dfa87969a4231ba7697/ groups-affiliated-black-lives-matter-release-agenda> (accessed October 27, 2016).

Wortley, Scot, Ross Macmillan, and John Hagan (1997). Just Des(s)erts?: The Racial Polarization of Perceptions of Criminal Injustice. Law and Society Review, 31: 637-676.

Wozniak, Kevin H. (2016). Perceptions of Prison and Punitive Attitudes: A Test of the Penal Escalation Hypothesis. Criminal fustice Review, 41(3): 352-371. 